\title{
Evaluation of industrial relations mechanism in trade dispute settlement in Ahmadu Bello University, Zaria (2003-2015)
}

\begin{tabular}{|c|c|}
\hline \multicolumn{2}{|c|}{$\begin{array}{l}\text { Authors: } \\
\text { Samuel Otohinoyi }{ }^{1} \\
\text { Weinoh Oboromeni }^{2} \\
\text { Seth I. Christopher }\end{array}$} \\
\hline \multicolumn{2}{|c|}{$\begin{array}{l}\text { Affiliations: } \\
{ }^{1} \text { Public Administration } \\
\text { Department, Ahmadu Bello } \\
\text { University, Nigeria }\end{array}$} \\
\hline \multicolumn{2}{|c|}{$\begin{array}{l}{ }^{2} \text { Human Resources Division, } \\
\text { Federal University, Nigeria }\end{array}$} \\
\hline \multicolumn{2}{|c|}{$\begin{array}{l}\text { Corresponding author: } \\
\text { Samuel Otohinoyi, } \\
\text { editor2rpam@yahoo.co.uk }\end{array}$} \\
\hline \multicolumn{2}{|c|}{$\begin{array}{l}\text { Dates: } \\
\text { Received: } 13 \text { Jan. } 2017 \\
\text { Accepted: } 08 \text { June } 2017 \\
\text { Published: } 28 \text { Aug. } 2017\end{array}$} \\
\hline \multicolumn{2}{|c|}{$\begin{array}{l}\text { How to cite this article: } \\
\text { Otohinoyi, S., Oboromeni, } \\
\text { W. \& Christopher, S.I., 2017, } \\
\text { 'Evaluation of industrial } \\
\text { relations mechanism in trade } \\
\text { dispute settlement in } \\
\text { Ahmadu Bello University, } \\
\text { Zaria (2003-2015)', Africa's } \\
\text { Public Service Delivery and } \\
\text { Performance Review 5(1), } \\
\text { a130. https://doi.org/ } \\
\text { 10.4102/apsdpr.v5i1.130 }\end{array}$} \\
\hline \multicolumn{2}{|c|}{$\begin{array}{l}\text { Copyright: } \\
\text { (C) 2017. The Authors } \\
\text { Licensee: AOSIS. This } \\
\text { is licensed under the } \\
\text { Creative Commons } \\
\text { Attribution License. }\end{array}$} \\
\hline \multicolumn{2}{|l|}{ Read online: } \\
\hline 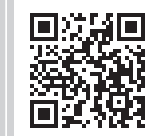 & $\begin{array}{l}\text { Scan this QR } \\
\text { code with your } \\
\text { smart phone or } \\
\text { mobile device } \\
\text { to read online. }\end{array}$ \\
\hline
\end{tabular}

Trade unions encounter conflicts in their work environment which are referred to as trade disputes. Nigerian laws have provided legal, institutional and administrative mechanisms for the resolution of trade disputes like the Trade Disputes Act. The study assessed the effectiveness of industrial relations mechanisms in trade dispute settlement. Data for the study were generated from primary and secondary sources. The instrument of primary data utilised includes questionnaires and interview methods; secondary sources include published and unpublished materials. The instruments were used on the respondents to test the two hypotheses formulated; qualitative and quantitative methods of data analyses were also used in the study with more emphasis on the quantitative method using chi-square statistical tool to test the hypotheses. The study revealed that industrial relations mechanism process promotes industrial harmony in Ahmadu Bello University (ABU), Zaria. Besides, the study found that breach of collective agreement leads to trade disputes in ABU, Zaria. The study recommended that industrial relations mechanism process as stipulated in the Trade Dispute Act should be strictly adhered to as it promotes industrial harmony. Also, collective agreement reached by the actors during their round table discussion or collective bargaining process should be complied with by all the parties involved as it was the outcome of their round table discussion which both parties actively participated in.

\section{Introduction}

\section{Background of the study}

Industrial relations has become one of the most delicate and complex problems of modern industrial society. With advancement in communication and information technology, the way work is organised and performed in organisations has really improved. Advancement in technology has also changed the relationship that had earlier existed between the employers and the employees. In the modern and competitive organisation, there is neither total monopoly of power by employers nor with the employees. However, social divide, which had favoured owner or employer at the expense of the employees, domination and difference in interest and values are still sources of conflicts in all organisations (Dauda 2007).

It is imperative to note that the central issue of industrial relations is how to attain and maintain maximum or optimum levels of productive efficiency and how to share the economic returns. There are divergences in the objectives and roles of the parties involved in the production process, that is, the employers and employees. While employers seek to maximise their profits, the employees strike through their trade unions to set equitable share in the profits which their labour has helped to generate. As a result of these differences and conflicting interests that are at play in at the organisations, problems are bound to arise.

As workers desire recognition, satisfaction, fair wages and salaries, job security, redress of wrongs and good working conditions in like manner, the employers seek to secure labour at the price that allows a reasonable margin for investment and further expect an uninterrupted production and distribution of goods and supply of services which is planned on a calculated cost and risk (Audi 1993). Government for its own part desires a well-regulated relationship between and among the industrial relation actors for a virile economy. Consumers do also expect from the manufacturers not only a fair price of goods and services, but also good quality of such goods or services (as the case may be). The processes that have been used particularly in Western developed countries for the attainment of these goals and aspirations of all the parties involved include collective bargaining. In Nigeria, like in most of the developing world, if collective bargaining fails, 
because of the inability of the actors to reach consensus, other statutory methods are followed, that is, mediation, conciliation and so on. The stability enjoyed in the educational system in advanced countries like Britain, Germany, USA and so on is because of their adherence to mechanisms for resolving disputes which is not the case in Nigeria. For the past two decades, the rate of industrial disputes in our educational sector for example is alarming, i.e.: in 1999, Academic Staff Union of Universities (ASUU) went on strike for five months; in 2001 ASUU was on strike for a period of three months; in 2003 another strike took place which lasted for a period of six months; in 2009 students were forced to stay at home for a period of four months as a result of strike and in the following year (2010) ASUU went on strike for another five months; in 2011 ASUU went on strike for a period of three months; 2013 for two months and so on. These series of industrial actions have had negative effects on the quality of students graduating from our universities. Also, these industrial actions embarked by the union (ASUU) have made the universities lose some of their prominent lecturers through either voluntary resignation or forceful disengagement by the management. Despite the efforts of the stakeholders to proffer solutions to the incessant conflicts between the parties which have affected the dissemination of knowledge in our universities, their efforts almost yielded nothing even with the existing mechanism put in place to foster unity among these actors involved in our educational sector, i.e. collective bargaining and Alternative Dispute Resolution (ADR) (Audi 2007; Ojeifo 2014; Orifowomo \& Ashiru 2015).

The problem is why is it that for the past two decades conflicts keep recurring in our universities among these actors despite the mechanisms put in place to maintain unity and cordial relations in order to achieve set objectives in the Nigerian university system?

Other questions that the study addressed are:

1. Are the industrial relations mechanisms effective in trade disputes settlement between the management and ASUU in Ahmadu Bello University (ABU), Zaria?

2. Are there breaches of disputes settlement process by ASUU or management in ABU, Zaria?

3. Are agreements reached and signed by disputed parties implemented in ABU, Zaria?

4. What are the effects of non-implementation or compliance with collective agreement in ABU, Zaria?

\section{Objective of thearticle}

The central objective of this research work was to evaluate the effectiveness of mechanisms for resolving trade disputes and reasons responsible for recurring trade disputes in ABU, Zaria.

\section{Hypotheses}

In order to achieve the objectives stated above, the following hypotheses have been formulated:
$\mathrm{H}_{0} 1$ : Industrial relations process does not promote industrial harmony in $\mathrm{ABU}$, Zaria.

$\mathrm{H}_{0} 2$ : Breach of collective agreement does not lead to trade disputes in $\mathrm{ABU}$, Zaria.

\section{Research method}

For the purpose of this study, the researchers adopted the survey and documentary research method. The researchers made use of oral interview, questionnaire textbooks, internet, journals and other published and unpublished materials. In order for the researchers to analyse data collected, the use of qualitative and quantitative method was explored using chisquare $\left(\chi^{2}\right)$ statistical tool to test the hypothesis.

The population size of the research work covers all the ASUU members and management staff of ABU, Zaria. The entire population of study covered 1695 management and academic staff members of $\mathrm{ABU}$, Zaria (office of the Registrar of ABU, 2015).

Sample population is drawn using the Steely Yamane (1967) as expressed by Israel (1993) popularly known as Yamane's formula calculated in Equation 1 below:

$n=\frac{N}{1+n(e)^{2}}$

where:

$$
\begin{aligned}
& n=\text { sample size } \\
& N=\text { population } \\
& e=\text { significant level of }(0.07) \\
& n=\underline{1695}=\underline{1695}=\underline{1695}=182 \\
& 1+1695(0.07)^{2} 1+1695 \times 0.00499 .3055
\end{aligned}
$$

[Eqn 1]

Based on the Yamane's formula computed above, the sample size for this study is 182. Questionnaires were therefore administered using stratified sampling technique to management and ASUU members in ABU, Zaria. This technique is considered best for this study because the researcher is dealing with two subgroups, that is, ASUU members and the management staff, which may have different views or opinions about the variables under study. Also, purposive sampling technique was adopted because the participants selected were information-rich in terms of the purpose of the study.

\section{Literature review and theoretical framework \\ Review of related literature \\ The concept of industrial relations}

The concept 'industrial relations' comprises two terms: 'industry' and 'relation'. Industry has been defined in Section 2 (j) of the Industrial Disputes Act 1947 as 'any business, trade, undertaking, manufacture or calling of employers and 
include any calling, service, employment, handicraft, or industrial occupation or a vocation of work men'. The term industry also refers to 'any productive activity in which an individual(s) is (are) engaged'. 'Relation' was defined in the Act to mean 'the relationship that exists within the industry between the employer and his employees or workmen' (Sharma 2014:1).

\section{Concept of trade dispute}

Trade dispute has been defined by Section 55 of the Trade Unions Decree 1973 as 'any dispute between employers and workers, or between workers and workers, which is connected with employment or non-employment or terms of employment or conditions of work of any person'. From the above definition, it means that a trade dispute is between two great social powers of an industry: labour and management.

\section{Mechanisms for disputes settlement}

According to Folayan (1998), Fajana (2000) and Onah (2008), the 1976 Trade Disputes Decree has provided two features of settling trade disputes. The first part encourages free collective bargaining, which is the normal process of settling trade disputes. The second part makes provision for alternative processes which is compulsory in nature where the normal process fails, namely mediation, arbitration and adjudication. Under the first part, which is collective bargaining, the parties are given the chance to reach an agreement on their own under Sections 2, 3 and 6. Where collective bargaining process (voluntary) fails, then begins the compulsory statutory methods. Under Section 7 of the Act, the minister is to refer the dispute to an arbitration panel within 14 days. Section 9 (2) of the Act also gives the minister the power to refer disputes to the National Industrial Court (NIC) where notice of objection has been served within the stipulated time from the award for the arbitration panel.

In summary, according to Folayan (1998), Fajana (2000) and Onah (2008), the mechanisms of settlement of trade disputes entail any of the following:

- collective bargaining, which is a voluntary process

- the statutory procedure embodied in the Trade Disputes Act of 1976, now Cap.T8, Laws of the Federation of Nigeria, 2004 . This is compulsory in case the collective bargaining fails.

Collective bargaining: Collective bargaining refers to negotiations about working conditions and terms of employment between an employer or a group of employers on the one hand and one or more representative of workers of an organisation on the other hand, with a view to reaching agreement. It is a means for resolving conflicts between labour and management (government). This means that the concept can be used as a process of agreeing to the terms and conditions of the agreement between the ASUU and the federal government through their respective representatives (Oleyele 2015).
The statutory procedure: Another important industrial relations mechanism has to do with statutory procedure embodied in the Trade Disputes Act of 1976. Statutorily, Section 3(1) of the Trade Disputes Act stipulates that any dispute arising in industry must first be settled under internal machinery, and only when this fails can the statutory procedure be resorted to. In case the internal machinery of each organisation fails, the law requires the parties to resort to the following formal statutory institutions: mediation, conciliation, arbitration, board of inquiry and, finally, NIC. The NIC Act provides adjudication at the NIC as the final point of call of trade dispute resolution except for an appeal from the NIC to the court of appeal in questions involving fundamental rights as contained in chapter IV in the Constitution of the Federal Republic of Nigeria 1999.

Mediation: By virtue of Section 4(2) of the Trade Disputes Act, where an attempt to settle the trade dispute through collective bargaining fails or if no such agreed means of settlement exists, the parties shall within seven (7) days of the date on which the dispute parties first met together either by themselves or through their representatives under the presidency of a mediator mutually agreed upon and appointed by or on behalf of the parties, with a view to amicable settlement of the dispute. This notwithstanding, where a trade dispute is apprehended by the minister, they may in writing inform the parties of their apprehension and the steps they intend to take in order to resolve the dispute. Any of such steps could be by bypassing the process of mediation to refer the dispute for conciliation or arbitration or to a board of inquiry.

Conciliation: In Section 8 ( 3 \& 5) of the Trade Disputes Act, the Minister of Labour shall, if not satisfied that the requirements for mediation have been substantially complied with, issue to the parties a notice specifying those requirements and may specify in the notice the time within which any such steps must be taken. If the time given on the notice expires or if no period is given, after the expiration of 14 days, the dispute remains unsettled and the minister is satisfied that the steps specified in the notice have been taken or that either party is refusing to comply, they shall appoint a fit person to act as a conciliator for the purpose of settlement of the dispute. The conciliator is expected to inquire into the causes and circumstance of the dispute and effect its settlement within seven days. After settlement, the conciliator shall report to the minister and forward to them the memorandum of the terms of settlement signed by the representatives of the parties. Such a memorandum shall be binding on the employers and worker to whom it relates from the date it was signed or such other date as may be specified therein.

Arbitration: The Trade Disputes Act established the industrial arbitration panel (IAP) which shall consist of a chairman, a vice-chairman and no fewer than 10 other members all of whom shall be appointed by the minister. A trade dispute may be referred to the arbitration tribunal under sections 5, 7 and 9 of the Trade Disputes Act. It is the duty of the chairman 
of the industrial arbitration tribunal to constitute the arbitration tribunal. The arbitration tribunal shall make its award within 21 days of its constitution or such longer period as the minister may in any particular case allow. The arbitration tribunal shall not communicate its award to the affected parties but shall make a copy available to the minister who may consider it desirable to refer the award back to the tribunal.

Board of inquiry: The Trade Disputes Act provides in Section 33 that where a trade dispute exists or is apprehended, the minister may cause an inquiry to be made into the causes and circumstances of a dispute by a board of inquiry. The board of inquiry is required to look into the matter and report its findings to the minister. The Act however is silent on whether the minister can make a binding award based on the findings of the board of inquiry.

National Industrial Court: Section 254c of the Constitution of the Federal Republic of Nigeria (Third Alteration) Act 2010 ('the Constitution') confers exclusive jurisdiction on the NIC with respect to civil and criminal matters relating to labour including trade unions and industrial relations, environment and conditions of work, health, safety and welfare of the workforce and matters of industrial relations. The court also exercises similar jurisdiction in matters relating to the grant of any order to restrain a person or body from taking part in any strike, lock-out or industrial action or any question as to the interpretation of any collective agreement, any award made by an arbitral tribunal in respect of a labour dispute or an organisation dispute. The NIC Act also confers powers on the court to grant injunctive reliefs as well as to make orders of mandamus, prohibition or certiorari, to appoint a public trustee for the management of the affairs and finances of a trade union or employers' organisation and to award compensation or damages.

\section{Review of past empirical studies}

The issue of industrial relations is of great concern to scholars in the field of administration and law. Various studies have been undertaken to determine the contributions of industrial relations to the sustainability and advancement of organisation. Some of these studies are reviewed in this section.

Ajibua (1998) in his study entitled Management of trade disputes and collective bargaining in the federal civil services investigated reasons for workers embarking on industrial strike actions in spite of the mechanism available for peaceful settlement. His study had the objective of finding out the effectiveness of this mechanism (collective bargaining) in disputes resolutions in the Nigerian civil service. The sample size of his study was 500 , which were drawn from various federal ministries with the office of Head of Service of the federation, officials of the IAP and officials of the NIC inclusive. To him, both the junior and senior staff were proportionally represented in his sample size. Ajibua adopted the pluralist approach as his theoretical framework. He elucidated that the pluralist system saw trade disputes as an expression of the fundamental conflict in the employment relationship which could be triggered by various government policies, management incompetence, increase in the cost of living, the paradox of affluence, shows of solidarity with other workers and non-implementation of collective agreement. Ajibua's study revealed that dispute settlement mechanism in the federal civil service was ineffective. He recommended that government should promote the use of collective bargaining in resolving disputes rather than waiting until workers feel they have been pushed to the wall, thereby reacting in a manner they consider appropriate which always results in the government taking draconian measures to deal with the situation. As we have thus seen above, Ajibua gave a detailed account on how the internal mechanism (collective bargaining) could be used in enhancing organisational harmony. Unfortunately, he did not justify the rationale behind the ineffectiveness of the dispute settlement mechanism. Also, he could not expatiate on how the pluralist approach can be used to promote industrial harmony.

With this general caveat in mind, we shall see in this study how our theoretical framework can be adopted in promoting industrial harmony between the management and ASUU in the university system.

Sule (1995) in his study ASUU strike and the law: a study of Ahmadu Bello University investigated the rationale behind the use of strike in achieving the goal and demands of a trade union and its consequences on our educational systems. Sule stated that the mechanism for resolving trade dispute were both collective bargaining (internal mechanism) and statutory provision as listed in the Trade Disputes Act which are mediation, conciliation, arbitration and NIC. The study revealed that although strike was illegal based on the provision of the Trade Disputes Act of 1976 it was necessary under the principle of collective bargaining as it was the ultimate sanction against management in securing concession by the union. The study also revealed that non-implementation of collective agreement led to series of strike action in our universities. He then added that strikes had contributed a lot of setback in the nation's education system over the years. Sule made effort to unveil reasons behind the use of strike by trade unions as tool for meeting their demands, but his study lacked quantitative analysis to prove his findings. He did not state the sample size of his study. The study also lacked theoretical underpinning to base his argument.

\section{Theoretical framework}

\section{The conflict management theory}

The propounder of the conflict management theory is Mary Parker Follett (1868-1933). Follett in Ngu (2010b) argued that conflict couldn't be eliminated in any organisation because it was an inevitable phenomenon where two or more people are brought together to achieve a predetermined end. To her, conflict is an exhibition of differences in ideas or opinions on given situations. She opines that conflict could be bad or 
good or neither bad nor good depending on the situation. Conflict could also provide good or bad results or outcome depending on the manner it is interpreted, understood and resolved by the actors that are affected. In an article entitled 'Constructive Conflict', she noted three methods of conflict resolution, namely domination, compromise and integration.

According to Follett, conflict resolution through domination is not the best option for any organisation because this would entail victory of one actor over the other. It would require the use of force and suppression of the weaker actor by the strong. Using this approach in conflict resolution does not mean victory has gone to the right party or that it has marked the end of the conflict.

Follett also recognised compromise as an alternative method of conflict resolution in an organisation. Under this method, each actor in the conflict situation surrenders certain values or interest in order for peace to reign. She warns that a conflict resolved through this method is not the best because it may suspend the conflict, yet a greater magnitude of the problem is likely to resurface in either the same form or in an entirely different manner.

Integration is the third method of conflict resolution as recommended by Mary Parker Follett. She approved the integration method as the best method for conflict resolution in organisations. To resolve a conflict through integration, each actor has to recognise the importance of x-raying all the various aspects of the conflict to be put forward for discussion, usually in a round table conference.

The relevance of this theory to this study lies in the fact that our universities consist of people who come together with the intention or purpose of achieving a given task; as such, conflict is inevitable in such arena. As suggested by Follett, conflict can be resolved through either of the following methods: domination, compromise and integration.

The Nigerian universities are made up of actors (lecturers and management) who must interact together for the purpose of achieving the system objectives and goal. In the course of interaction, differences in ideas or opinions on a given situation may arise which if not properly handled might result in trade dispute. However, the need for the survival and continuity of the universities means that conflicts need to be handled in such a way that the actors involved do not necessarily bring about severe and damaging consequences to the system.

Analysing the conflict resolution methods, the domination approach by management might not bring the expected industrial harmonies to the Nigerian university system. This is because the attitudes to win all for one selves (management) and deny any for the other party (ASUU) will not augur well in trade disputes settlement. More so, the compromise approach (though preferable to domination) shows the readiness of the actors to find a common ground for a solution. However, based on Follet's postulations, the researchers are of the opinion that the best of all is the integration approach because the divergent interests or demands of these actors are critically analysed or put forward for discussion in a round table conference with the aim of coming out with lasting solution to the cause of the dispute. Therefore, if the actors in our university system can integrate their demands with the intention of proffering solutions to crises that have characterised our universities for more than two decades, the industrial harmony that has eluded the system will be restored again. This will create room for progress and sustainability in our educational system.

\section{Data presentation, analysis and interpretation}

A total number of 182 questionnaires based on the sample size selected were administered to both management staff and ASUU members in ABU, Zaria in order to obtain relevant information with regard to how effective conflict resolution mechanisms are in achieving industrial harmony in the Nigerian universities with particular reference to ABU, Zaria. Out of these 182 questionnaires administered, 115 representing $63 \%$ were filled and returned, while 67 of the questionnaires representing $37 \%$ were not returned.

\section{Decision rule}

Accept the null hypothesis $\left(\mathrm{H}_{0}\right)$, if chi-square $\left(\chi^{2}\right)$ calculated value is less than $\chi^{2}$ tabulated and reject the alternative hypothesis $\left(\mathrm{H}_{1}\right)$. However, if $\chi^{2}$ calculated is greater than $\chi^{2}$ tabulated, reject null hypothesis $\left(\mathrm{H}_{0}\right)$ and accept alternative hypothesis $\left(\mathrm{H}_{1}\right)$.

\section{Respondents' characteristics and classification}

Tables 1 and 2 show the demographic variables of respondents in frequencies and their corresponding percentages. This will allow us to give a clear picture of the results of these variables.

As shown in Table 1, $3(3 \%)$ of the respondents were principal officers of $A B U$, Zaria, while 112 (97\%) of the respondents were ASUU members in ABU, Zaria. Also as shown in Table 2, 54 (47\%) of the respondents were hired into these universities during the period under study, while $61(53 \%)$ of the respondents were already in the system before the scope of the study. This means that they will have

TABLE 1: Position.

\begin{tabular}{lcc}
\hline Options & Frequency & Total frequency (\%) \\
\hline Principal officer & 3 & 3 \\
Lecturer & 112 & 97 \\
\hline Total & $\mathbf{1 1 5}$ & $\mathbf{1 0 0}$ \\
\hline
\end{tabular}

Source: Researcher's field survey 2015

TABLE 2: Years in service.

\begin{tabular}{lcc}
\hline Options & Frequency & Total frequency (\%) \\
\hline 1-10 years & 54 & 47 \\
Above 10 years & 61 & 53 \\
\hline Total & $\mathbf{1 1 5}$ & $\mathbf{1 0 0}$ \\
\hline
\end{tabular}

Source: Researcher's field survey 2015 


\begin{tabular}{|c|c|c|c|c|c|c|c|}
\hline \multicolumn{4}{|l|}{ Observed frequency } & \multicolumn{4}{|c|}{ Expected frequency } \\
\hline Industrial relations process and industrial harmony & Yes & No & Total & Industrial relations process and industrial harmony & Yes & No & Total \\
\hline Collective bargaining and dispute settlement & 104 & 11 & 115 & Collective bargaining and dispute settlement & 76.52 & 38.48 & 115 \\
\hline Impact of collective bargaining & 83 & 32 & 115 & Impact of collective bargaining & 76.52 & 38.48 & 115 \\
\hline Mediation, conciliation and cordial relations & 97 & 18 & 115 & Mediation, conciliation and cordial relations & 76.52 & 38.48 & 115 \\
\hline Failure of mediation and conciliation & 57 & 58 & 115 & Failure of mediation and conciliation & 76.52 & 38.48 & 115 \\
\hline Arbitration and cooperation & 55 & 60 & 115 & Arbitration and cooperation & 76.52 & 38.48 & 115 \\
\hline Failure of arbitration & 60 & 6 & 66 & Failure of arbitration & 43.92 & 22.08 & 66 \\
\hline \multirow[t]{2}{*}{ Failure of adjudication } & 20 & 13 & 33 & Failure of adjudication & 21.96 & 11.04 & 33 \\
\hline & 525 & 264 & 789 & & 525 & 264 & 789 \\
\hline
\end{tabular}

Source: Survey 2015

full understanding of what the researcher is investigating on in their university.

\section{Collective bargaining and dispute settlement}

Under this variable, the respondents were asked whether collective bargaining has helped in enhancing industrial harmony in their university. The results show that collective bargaining is an effective mechanism in enhancing industrial harmony. This was opined by the 104 (90\%) of the respondents who agreed that collective bargaining has helped in enhancing industrial harmony in $\mathrm{ABU}$, Zaria. Therefore, these responses go contrary to the null hypothesis 1 which states that 'industrial relations mechanism process does not promote industrial harmony in ABU, Zaria'. This goes in line with one aspect of the theoretical framework adopted in this study as propounded by Mary Parker Follett (integration), while $11(10 \%)$ responded in favour of the postulated null hypothesis.

\section{Extent of industrial harmony}

Under this variable, the respondents were asked to comment on the degree to which they think collective bargaining has helped in promoting cordial relation between management and ASUU in their university. Twenty (17\%) of the respondents believed that the degree to which collective bargaining has helped in promoting industrial harmony is very high, while $79(69 \%)$ of the respondents opined that the degree to which collective bargaining has helped in promoting industrial harmony is high. Fourteen $(12 \%)$ of the respondents agreed that the degree to which collective bargaining has helped in promoting industrial harmony is low in ABU, Zaria. Only two $(2 \%)$ of the respondents opined that the degree to which collective bargaining has helped in promoting industrial harmony is very low in ABU, Zaria. These responses go contrary to the null hypothesis 1 which states that industrial relations mechanism process does not promote industrial harmony in $\mathrm{ABU}$, Zaria.

\section{Impact of collective bargaining}

The respondents were asked under this variable whether most industrial disputes between the management and ASUU were resolved through collective bargaining in their university. Eighty-three (72\%) of the respondents agreed that most industrial disputes between the management and
ASUU in ABU, Zaria, were resolved through collective bargaining, while $32(28 \%)$ of the respondents believed that most industrial disputes between the management and ASUU in ABU, Zaria, have not been resolved through collective bargaining.

\section{Mediation, conciliation and cordial relations}

Under this variable, the respondents were asked whether the intervention of mediators and conciliators in disputes resolution has helped significantly in promoting cordial relations between the management and ASUU in their university. The results show that mediation and conciliation are effective mechanisms in promoting cordial relations between the management and ASUU. This was opined by $97(84 \%)$ of the respondents who agreed that intervention of mediators and conciliators in disputes resolution has helped significantly in promoting cordial relations between the management and ASUU in ABU, Zaria. This goes contrary to postulated null hypothesis 1 (see Table 3 ) which states that 'industrial relations mechanism process does not promote industrial harmony in ABU, Zaria', while 18 (16\%) of the respondents believed that the intervention of mediators and conciliators in disputes resolution has not helped significantly in promoting cordial relations between the management and ASUU in ABU, Zaria.

\section{Failure of mediation and conciliation}

Under this variable, the respondents were asked whether the management and ASUU resort frequently to arbitration upon the failure of mediation and conciliation in trade disputes settlement in their university. Fifty-seven (50\%) of the respondents opined that management and ASUU resort frequently to arbitration upon the failure of mediation and conciliation mechanisms in trade disputes settlement in ABU, Zaria, while $58(50 \%)$ of the respondents believed that the management and ASUU do not resort frequently to arbitration upon the failure of mediation and conciliation mechanisms in trade dispute settlement in ABU, Zaria.

\section{Arbitration and cooperation}

Under this variable, the respondents were asked whether the use of IAP fostered cooperation between the management and ASUU in their university. Fifty-five (48\%) of the respondents agreed that the use of IAP fostered cooperation between the management and ASUU in ABU, 
Zaria, while $60(52 \%)$ of the respondents opined that IAP did not foster cooperation between the management and ASUU in ABU, Zaria.

\section{Arbitration and resolution}

Under this variable, the respondents were asked whether IAP has ever resolved industrial dispute between the management and ASUU in their university. Forty-nine $(43 \%)$ of the respondents opined that IAP has ever resolved industrial disputes between the management and ASUU in ABU, Zaria, while 66 (57\%) of the respondents believed that IAP has never resolved industrial disputes between the management and ASUU in ABU, Zaria.

\section{Failure of arbitration}

Under this variable, the respondents were asked whether the aggrieved party resorted to any other industrial relation mechanism of trade dispute settlement upon the failure of arbitration in their university. Sixty (91\%) of the respondents opined that the aggrieved party resorted to another industrial relations mechanism of trade disputes settlement upon the failure of arbitration in ABU, Zaria, while 6 (9\%) of the respondents believed that the aggrieved party did not resort to any other industrial relation mechanism upon the failure of arbitration in ABU, Zaria. This implies that other trade dispute settlement mechanisms are followed when arbitration fails as nearly all respondents agreed to this.

\section{Adjudication and otherwise (self-help approach)}

The respondents were asked under this variable which mechanism of trade dispute settlement is adopted or otherwise in trade dispute settlement in their university. Twenty-seven (45\%) of the respondents agreed that the self help approach was adopted upon the failure of arbitration in resolving trade disputes in $\mathrm{ABU}$, Zaria, while 33 (55\%) of the respondents agreed that the adjudication approach NIC was what the aggrieved party resorted to upon the failure of arbitration in ABU, Zaria.

\section{Self-help approach}

Under this variable, the respondents were asked whether the 'self-help approach' is effective in creating an atmosphere of industrial harmony in their university. The respondents were of the view that the approach is quite effective in achieving their union's demand from the university management. They added that the method does not promote industrial harmony in their universities, but it only serves as a last resort for the union to press its demands.

\section{Failure of adjudication}

Under this variable, the respondents were asked whether the adjudication approach was quite effective in resolving industrial disputes in their university. Twenty (61\%) of the respondents agreed that the adjudication approach was quite effective in resolving industrial disputes in $\mathrm{ABU}$, Zaria, while 13 (39\%) of the respondents opined that the adjudication approach was not quite effective in resolving industrial disputes in $\mathrm{ABU}$, Zaria.

In computing the degree of freedom, we now have equation 2:

$$
\begin{gathered}
V=(\text { Rows }-1)(\text { Columns }-1)=(8-1)(2-1) \\
=7 \times 1=7
\end{gathered}
$$

The value of the cut-off points of chi-square $\left(\chi^{2}\right)$ for 7 degree of freedom from chi-square $\left(\chi^{2}\right)$ table at 0.05 or $5 \%$ level of significance is 14.07 .

\section{Decision}

From the computations shown in Table 4 , chi-square $\left(\chi^{2}\right)$ calculated value of 128.18 is greater than chi-square $\left(\chi^{2}\right)$ critical value of 14.07 . To this end, the null hypothesis $\left(\mathrm{H}_{0}\right)$ would be rejected. This shows that industrial harmony depends largely on adherence to industrial relations mechanism processes in $\mathrm{ABU}$, Zaria.

\section{Collective agreement}

Under this variable, the respondents were asked whether collective agreement had been reached by ASUU and the management in their university. As many as 108 (94\%) of the respondents opined that collective agreement had been reached between the management and ASUU in ABU, Zaria, while $7(6 \%)$ of the respondents believed that collective agreement had not been reached between management and ASUU chapter of ABU, Zaria.

\section{Adherence to collective agreement}

The respondents were asked under this variable to comment on how they viewed adherence to collective agreement reached by the management and ASUU in their university. Twenty-three (20\%) of the respondents agreed that management and ASUU strictly adhered to collective agreement in $\mathrm{ABU}$, Zaria, while 89 (77\%) opined that

\begin{tabular}{lcrrr}
\multicolumn{5}{l}{ TABLE 4: Computation of $\chi^{2}$ calculated. } \\
\hline $\mathbf{O}$ & $\mathbf{E}$ & $\mathbf{O}-\mathrm{E}$ & \multicolumn{1}{c}{$(\mathbf{O}-\mathrm{E})^{2}$} & $(\mathbf{O}-\mathrm{E})^{2} /_{\mathrm{E}}$ \\
\hline 104 & 76.52 & 27.48 & 755.1500 & 9.87 \\
83 & 76.52 & 6.48 & 41.9900 & 0.55 \\
97 & 76.52 & 20.48 & 419.4300 & 5.48 \\
57 & 76.52 & -19.52 & 381.0304 & 4.98 \\
55 & 76.52 & -21.52 & 463.1104 & 6.05 \\
49 & 76.52 & -27.52 & 757.3504 & 9.90 \\
60 & 43.92 & 16.08 & 258.5664 & 5.89 \\
20 & 21.96 & -1.96 & 3.8416 & 0.17 \\
11 & 38.48 & -27.48 & 755.1504 & 19.62 \\
32 & 38.48 & -6.48 & 41.9904 & 1.09 \\
18 & 38.48 & -20.48 & 419.4304 & 10.90 \\
58 & 38.48 & 19.52 & 381.0304 & 9.90 \\
60 & 38.48 & 21.52 & 463.1104 & 12.04 \\
66 & 38.48 & 27.52 & 757.3504 & 19.68 \\
6 & 22.08 & -16.08 & 258.5664 & 11.71 \\
13 & 11.04 & 1.96 & 3.8416 & 0.35 \\
\hline & & & Total & 128.18 \\
\hline $50 u r e$ & 2015 & & &
\end{tabular}

Source: Survey 2015 
management and ASUU partially adhered to collective agreement reached in ABU, Zaria. Only $3(3 \%)$ of the respondents believed that there was no adherence between management and ASUU in ABU, Zaria.

\section{Prompt to compliance}

Under this variable, the respondents were asked to comment on how urgently ASUU and management had complied with collective agreement in their university. Thirty-one (27\%) of the respondents opined that management and ASUU complied promptly with collective agreement in ABU, Zaria, while $84(73 \%)$ of the respondents agreed that management and ASUU had not promptly complied with collective agreement in $\mathrm{ABU}$, Zaria.

\section{Delay in compliance}

Under this variable, the respondents were asked whether delay in compliance to collective agreement ever led to trade dispute between the management and ASUU in their university. As many as 106 (92\%) of the respondents opined that delay in compliance to collective agreement led to trade dispute between management and ASUU in ABU, Zaria, while $9(8 \%)$ of the respondents believed that delay in compliance to collective agreement had not led to trade dispute in $\mathrm{ABU}$, Zaria.

\section{Full compliance to collective agreement}

Under this variable, the respondents were asked whether full compliance to collective agreement by management and ASUU would lead to resolution of trade dispute in their university. As many as 107 (93\%) of the respondents agreed that full compliance to collective agreement by management and ASUU would lead to resolution of trade disputes in $\mathrm{ABU}$, Zaria, while $8(7 \%)$ of the respondents opined that full compliance to collective agreement would not lead to resolution of trade disputes in ABU, Zaria.

\section{Difficulty in compliance}

Under this variable the respondents were asked about what they thought made compliance to collective agreement difficult in their university. The respondents opined that lack of funds, lack of transparency and accountability, selfcenteredness on the part of management and leadership style were some of the factors that made it difficult for ASUU or management to comply with agreement reached in ABU Zaria.
In computing the degree of freedom, we now have equation 3:

$V=($ Rows -1$)($ Columns -1$)=(5-1)(2-1)=4 \times 1=4[$ Eqn 3]

The value of the cut-off points of chi-square $\left(\chi^{2}\right)$ for 4 degree of freedom from chi-square $\left(\chi^{2}\right)$ table at 0.05 or $5 \%$ level of significance is 9.49 .

\section{Decision}

From the computations shown in Table 6, chi-square $\left(\chi^{2}\right)$ calculated value of 215.82 is greater than chi-square $\left(\chi^{2}\right)$ critical value of 9.49. To this end, the null hypothesis $\left(\mathrm{H}_{0}\right)$ would be rejected. Therefore, the hypothesis 2 (see Table 5) which states that 'breach of collective agreement leads to trade disputes in ABU, Zaria' is therefore accepted, as it has been proved beyond reasonable doubt by the five (5) variables. This shows that trade disputes depend largely on breach of collective agreement between ASUU and the management in $\mathrm{ABU}$, Zaria.

\section{Discussion of findings}

Discussion in research has been seen as the process of rationalisation based on the analyses and interpretation of data (Idisi \& Oshionebo 2003). In this section, the results of the data analyses are discussed for general understanding of the study.

The problem investigated in this study is the rationale behind the recurrence of disputes in ABU, Zaria, despite the mechanisms put in place to maintain unity and cordial relationships among the actors in this university. The hypotheses formulated, as earlier stated, were geared towards unravelling this puzzle. The major variables for testing the hypotheses as contained in the results and interpretation section formed the fulcrum of the discussion. These variables are not just industrial relations mechanism process for $\mathrm{ABU}$, Zaria, but also must be adhered to in resolving trade disputes in any organisation.

\section{Collective bargaining}

The researchers had discussions with some members of ASUU and the management on how collective bargaining has been utilised in resolving trade dispute in ABU, Zaria. We gathered that eventually all the trade disputes between

TABLE 5: Test of hypothesis two.

\begin{tabular}{|c|c|c|c|c|c|c|c|}
\hline \multicolumn{4}{|l|}{ Observed frequency } & \multicolumn{4}{|c|}{ Expected frequency } \\
\hline Breach of collective agreement and trade disputes & Yes & No & Total & Breach of collective agreement and trade disputes & Yes & No & Total \\
\hline Collective agreement & 108 & 7 & 115 & Collective agreement & 88.73 & 26.27 & 115 \\
\hline Delay in compliance & 106 & 9 & 115 & Delay in compliance & 88.73 & 26.27 & 115 \\
\hline Effect of compliance to enhance harmony & 107 & 8 & 115 & Effect of compliance to enhance harmony & 88.73 & 26.27 & 115 \\
\hline Adherence to collective agreement & 23 & 3 & 26 & Adherence to collective agreement & 20.06 & 5.94 & 26 \\
\hline Promptness of compliance & 31 & 84 & 115 & Promptness of compliance & 88.73 & 26.27 & 115 \\
\hline Total & 375 & 111 & 486 & Total & 375 & 111 & 486 \\
\hline
\end{tabular}

Source: Survey 2015 
TABLE 6: Computation of $\chi^{2}$ calculated.

\begin{tabular}{lcccc}
\hline $\mathbf{O}$ & $\mathrm{E}$ & $\mathrm{O}-\mathrm{E}$ & $(\mathrm{O}-\mathrm{E})^{2}$ & $(\mathrm{O}-\mathrm{E})^{2} /_{\mathrm{E}}$ \\
\hline 108 & 88.73 & 19.27 & 371.33 & 4.18 \\
106 & 88.73 & 17.27 & 298.25 & 3.36 \\
107 & 88.73 & 18.27 & 333.79 & 3.76 \\
23 & 20.06 & 2.94 & 8.64 & 0.43 \\
31 & 88.73 & -57.73 & 3332.75 & 37.56 \\
7 & 26.27 & -19.27 & 371.33 & 14.14 \\
9 & 26.27 & -17.27 & 298.25 & 11.35 \\
8 & 26.27 & -18.27 & 333.79 & 12.71 \\
3 & 5.94 & -2.94 & 8.64 & 1.46 \\
84 & 26.27 & 57.27 & 3332.75 & 126.87 \\
\hline Total & & & & $\mathbf{2 1 5 . 8 2}$ \\
\hline
\end{tabular}

Source: Survey 2015

these actors were always resolved through collective bargaining. They added that at the onset the mechanism may not have achieved the purpose of resolving the dispute but when other mechanisms failed, i.e. mediation, they will resort to negotiation again in resolving their differences. This is the rationale behind $104(90 \%)$ of the respondents in 'Collective bargaining and dispute settlement' section of the analysis section who opined that collective bargaining has helped in enhancing industrial harmony in ABU, Zaria. This goes in line with the integration approach adopted in our theoretical framework as propounded by Mary Parker Follet in her theory of conflict management.

\section{Mediation and conciliation}

The researchers gathered from the principal actors (management and ASUU) in ABU, Zaria, that the intervention of the mediators had been of great help in resolving disputes in their university. However, 'mediation, conciliation and cordial relations' section of the analysis section also confirmed that mediation and conciliation are effective mechanisms in promoting cordial relations between the management and ASUU in ABU, Zaria, where 97 (84\%) of the respondents attested to that assertion.

\section{Arbitration (Industrial Arbitration Panel)}

Section 9 (1) of Trade Disputes Act provides that the aggrieved party should resort to IAP upon the failure of mediation and conciliation. In related discussions with some members of ASUU and that of management of ABU, Zaria, the respondents submitted that they hardly employ this mechanism in resolving trade dispute in their university. The members of ASUU were of the view that proceeding to IAP will amount to time wasting. Also, the panel award (i.e. verdict) will be influenced by the government to favour the management because of the fact that the minister appoints those to function in the panel and the award of the panel must also be reported first to the minister before communicating it to the parties involved in the dispute. However, almost half of the respondents held a contrary view to the information gathered from the principal actors as shown in the 'arbitration and resolution' section of the analysis section.

\section{Adjudication (National Industrial Court)}

Based on our discussions with the principal actors (management and ASUU members) of ABU, Zaria, we gathered that these actors have never resorted to NIC for resolution of any dispute in their university. The ASUU members attested to the fact that strike is the only weapon used by the union in compelling the management to comply with their demands. Although, section 18 of the Trade Disputes Act 2004 prohibited lock-out and strike before issue of award of NIC, this shows that the processes for settlement of disputes are not being fully complied with in $\mathrm{ABU}$, Zaria. The inconsistency on the part of the respondents in answer to questions asked in the questionnaire (as seen in 'failure of arbitration' and 'adjudication and otherwise (self-help approach' sections) and the interview conducted with the principal actors shows that they were not being objective enough in their responses.

\section{Adherence to collective agreement}

The end product or the outcome of collective bargaining is referred to as collective agreement. Therefore, the parties involved in collective bargaining are supposed to adhere strictly to the agreement reached. Item 'adherence to collective agreement' of the analysis section revealed that the management and ASUU in ABU, Zaria, partially adhere to collective agreement reached as $89(77 \%)$ of the respondents supported the opinion. Our discussions with some principal officers and ASUU executives in ABU, Zaria, show that these actors hardly adhered strictly to collective agreement reached. We further gathered from the principal officers that the collective agreement reached with ASUU by the federal government of Nigeria at the national level cannot be strictly adhered to in their university without the government making necessary provision for its implementation.

\section{Urgency to comply}

The parties involved in collective agreement are supposed to comply promptly without any delay as it is the outcome of their negotiation. Item 'promptness of compliance' of the analysis section shows that the management and ASUU in $\mathrm{ABU}$, Zaria, have not promptly complied with collective agreement reached as $84(73 \%)$ of the respondents attested to such fact.

The researchers gathered from the discussions held with some principal officers and some ASUU executives in ABU, Zaria, that the major cause of not complying promptly to collective agreement in the university as shown in 'promptness of compliance' section has to do with lack of transparency, sincerity and accountability of principal actors in ABU, Zaria. Some ASUU executives informed the researcher that the principal officers are not transparent in their dealings with the ASUU when it comes to compliance to collective agreement. Some principal officers we spoke with were of the view that whenever resources are available 
to comply with collective agreement reached with ASUU, either at the national level by the federal government or not, the university will promptly respond to that agreement. This contention shows that there is a communication gap between ASUU and the principal officers in ABU, Zaria, on the ability of the university to meet the collective agreement reached. However, this further revealed that both parties lack mutual trust.

\section{Major findings of the study}

Among the findings, from the analysis of data discussed above, the following appeared most glaring:

1. That industrial relation mechanism processes promote industrial harmony in $\mathrm{ABU}$, Zaria.

2. That collective bargaining as an internal mechanism is an effective mechanism in resolving trade disputes as the management and ASUU of ABU, Zaria, confirm that various disputes between them were resolved through this mechanism.

3. That going on strike (self-help approach) does not promote industrial harmony although it compels the management to respond to the demands of ASUU more timeously than expected.

4. That the management and ASUU of ABU, Zaria, chapter hardly comply to the whole processes of resolving disputes as stipulated in the Trade Disputes Act 2004. This finding is in line with the interview conducted by the researcher which observed that principal actors hardly utilise IAP in resolving their disputes. Also, ASUU declaring strike without the award of NIC is a critical issue.

5. That breach of collective agreement leads to trade disputes in ABU, Zaria.

6. That delay in compliance to collective agreement leads to trade disputes. In many situations, delay in compliance to collective agreement brought about strikes in our Nigerian universities in general.

\section{Conclusion and recommendations}

Based on our findings from the analysis of data, we wish to draw the following conclusions.

Our finding on industrial relations mechanism processes and industrial harmony reveals that industrial relations mechanism processes promote industrial harmony in ABU, Zaria. The majority of the respondents in the 10 variables further confirmed this finding. Therefore, in the light of that, it was evidently proved that both internal mechanism (collective bargaining) and the statutory procedure embodied in the Trade Disputes Act of 1976 (now Cap. T8, Laws of the Federation of Nigeria, 2004) could constitute effective mechanisms for resolving trade disputes in the Nigeria public service.

Furthermore, this study reveals that breach of collective agreement leads to trade disputes in ABU, Zaria. This was because the majority of respondents in the four variables attested to such assertion.
In the light of the research findings, we therefore recommend that:

1. The industrial relations mechanism processes as stipulated in the Trade Disputes Act of 1976 (now Cap. T8, Laws of the Federation of Nigeria, 2004) should be strictly adhered to as they promote industrial harmony. This is because the attainment of industrial harmony in our universities is vital to educational development as it will ultimately affect positively the quality of graduates turning out from the Nigerian universities.

2. Based on the collective agreement reached by ASUU, either at the national level with the federal government or at the local level with the university councils, the parties involved should comply with all the terms agreed upon as it was the outcome of negotiation which both parties actively participated in.

3. Internal mechanisms (collective bargaining) should be effectively utilised in resolving trade disputes as they create room for parties involved in the dispute to discuss in detail how the problem should be resolved.

4. Employers should not wait for threat of strike or actual work stoppage before negotiating with unions on how to meet their demands.

5. Disciplinary measures should be taken against any employer or employers association or any employees or their representatives (unions) that refuse to comply with the stipulated or laid down procedures of resolving trade disputes as stated in the Trade Disputes Act.

\section{Acknowledgments}

First and foremost, we thank the Almighty, and we also thank Dr Chinyeaka Justine.

\section{Competing interests}

The authors declare that they have no financial or personal relationships which may have inappropriately influenced them in writing this article.

\section{Authors' contributions}

S.O. carried out the field work, review of literature and worked on the findings. W.O. did editing and interpretation of data. S.I.C. performed the calculations and analysis.

\section{References}

Ajibua, F.A., 1998, Management of trade dispute and collective bargaining in the federal civil service, unpublished project, Department of Public Administration, ABU, Zaria.

Audi, J.A.M., 1993, 'Strikes and the law in Nigeria', Journal of Law Students Society, Vol. 2.

Audi, J.A.M., 2007, 'Change in climate: The National Industrial Court Art, 2006 a vehicle for accelerating dispute settlement towards industrial harmony in Nigeria', Law Journal, Vol. 25-26.

Dauda, Y.A., 2007, 'Employment of independent arbitrators in the management of trade disputes and industrial crises in Nigeria', Nigeria Journal of Labour Law and Industrial Relations, Vol. 1, No. 1.

Fajana, S., 2000, Industrial relations in Nigeria: Theory and features, Longman, Lagos.

Folayan, O. 1998, Personnel Management: Theories and Issues, Panal Publishing, Inc., Lagos. 
Idisi, P. \& Oshionebo, B., 2003, Practical guide to thesis and project work, Kings and Queens System (Publishers) Ltd, Kaduna.

Ngu, S.M., 2010a, Principles and practice of personnel management in Nigeria Gaskiya Corporate Ltd., Zaria.

Ngu, S.M., 2010b, Motivation theory and workers compensation in Nigeria, Gaskiya Corporate Ltd., Zaria.

Ojeifo, S.A., 2014, 'ASUU industrial actions: Between ASUU and Government is it an issue of rightness?'Journal of Education and Practice, Vol. 5, No. 6.

Oleyele, A., 2015, 'How to solve the face-off between the federal government and ASUU (Blog post), viewed September 29, 2015, from http://zodml.org/blog/howsolve-face-between-federal-government-andasuu/
Onah, F. O., 2008, Multinational Corporations (MNCS) and development dilemma in Niger-Delta region, Nigeria. Millennium Journal of International Studies. Vol. 1 No. 1-14

Orifowomo, O.A. \& Ashiru, O., 2015, 'Settlement of trade disputes: Nigeria's labour court in perspectives', Journal of Law, Policy and Globalization, Vol. 37, No. 150.

Sharma, D.R., 2014, Overview of industrial relations, Macmilan India Limited, New Delhi, India.

Sule, U., 1995, ASUU strike and the law: A study of Ahmadu Bello University, unpublished LL.B project submitted to the Faculty of Law, ABU, Zaria.

Yamane, T., 1967, Statistics: An Introductory Analysis, 2nd edn., Harper and Rao, New York. 